\title{
Analysis of the inicial eight years of activities of the Human Heart Valve Bank of the Hospital de Caridade da Irmandade da Santa Casa de
} Misericórdia de Curitiba

\author{
Análise das atividades dos oito anos iniciais do Banco de Valvas Cardíacas Humanas do Hospital de \\ Caridade da Irmandade da Santa Casa de Misericórdia de Curitiba
}

Marise Teresinha Brenner Affonso da COSTA ${ }^{1}$, Francisco Diniz Affonso da COSTA ${ }^{2}$, Luciana Cristina Ferreti de $\mathrm{NAZARENO}^{3}$, Juliana DOMACHOSKI ${ }^{3}$, Ângela Maria PERUZZO ${ }^{3}$, Claudinei COLATUSSO ${ }^{4}$, Carlos Henrique Gori GOMES ${ }^{4}$, Iseu Affonso da COSTA ${ }^{5}$

RBCCV 44205-778

\begin{abstract}
Objective: The aim of this study was to retrospectively evaluate the first eight years of activities of the Human Heart Valve Bank of Hospital de Caridade da Irmandade da Santa Casa de Curitiba (BVCHSC), analyzing aspects related to procurement, processing, storage and distribution of homologous cardiovascular grafts.

Method: Initial donor screening was achieved according the national guidelines for human organ procurement, besides specific BVCHSC criteria. Hearts were obtained from multiple organ donors, non-beating heart donors and heart transplant recipients, with total ischemic times under 48 hours. Donor ages varied from neonates up to 60 years for aortic valves and 65 years for pulmonary valves. The dissected grafts had their dimensions measured and their morphology evaluated, using a classification system with category 0 (discarded), 1 (minimal morphological alterations) and 2 (perfect). The incidence and microorganisms responsible for organ contamination were determined, as was the efficiency of the decontamination solution. Aspects related to graft distribution were also analysed.
\end{abstract}

\footnotetext{
1 - Coordinator of the Human Heart Valve Bank of Santa Casa

2 - Surgeon in the Health Alliance of Santa Casa - PUCPR

3 - Human Heart Valve Bank

4 - Resident of the Heart Surgery Service of the Health Alliance of Santa Casa - PUCPR

5 - Head of the Heart Surgery Service of the Health Alliance of Santa Casa - PUCPR
}

Work performed in the Banco Human Heart Valve Bank of Santa Casa de Misericórdia de Curitiba. Curitiba, Paraná, Brazil.

Correspondence adds: Praça Rui Barbosa, 694. Centro. Curitiba, PR, Brazil. CEP: 80010-030.

E-mail: fcosta@mps.com.br
Results: From September 1996 to February 2005, 1059 hearts from 19 Brazilian states were received at BVCHSC. From these, $977(92.3 \%)$ were from brain-death donors. A total of 2105 grafts were processed and of the aortic and pulmonary grafts that were analysed, 783 were in category 2 , 697 in category 1 and 186 were discarded due to morphological abnormalities. In total, 433 received grafts were contaminated and the sterilization solution was efficient in $\mathbf{3 3 0}$ cases. $\mathbf{5 7 1}$ (27.1\%) grafts were rejected during some phase of the processing, mainly due to contamination and morphological abnormalities. A total of 1338 grafts were distributed to 74 health institutions and were more commonly used for aortic valve replacement (529), correction of congenital heart diseases (478) and during the Ross procedure (272).

Conclusions: The activities of the BVCHSC during the initial eight years were satisfactory, fulfilling the proposed goals.

Descriptors: Tissue banks. Transplantation, homologous. Cryopreservation. Tissue preservation. 


\section{Resumo}

Objetivo: O objetivo deste trabalho foi avaliar, retrospectivamente, os primeiros oito anos de funcionamento do Banco de Valvas Cardíacas Humanas do Hospital de Caridade da Irmandade da Santa Casa de Misericórdia de Curitiba (BVCHSC), analisando aspectos relacionados às atividades de captação, processamento, armazenamento e distribuição de enxertos homólogos cardiovasculares.

Método: A seleção inicial dos doadores seguiu as diretrizes nacionais para captação de órgãos humanos, além de critérios específicos do BVCHSC. Os corações foram obtidos de doadores de múltiplos órgãos, doadores em parada cardíaca e receptores de transplante cardíaco, com somatória dos tempos de isquemia inferior a 48 horas. A idade dos doadores variou desde recém-nascidos até 60 anos para as valvas aórticas e 65 para as pulmonares. Os enxertos dissecados tiveram suas dimensões mensuradas e sua morfologia avaliada, sendo classificados como categoria 0 (descartados), 1 (alterações morfológicas mínimas) ou 2 (perfeitos). Foram determinados a incidência e os germes responsáveis pela contaminação nos enxertos recebidos, assim como a eficiência da solução de descontaminação. Foram também avaliados aspectos relacionados à distribuição dos enxertos.

\section{INTRODUCTION}

Human heart valves have been used as replacement valves since 1962 and present some advantages over conventional prostheses, such as their physiological hemodynamic performance with central and laminar blood flow, almost no thromboembolism, avoiding the use of anticoagulants and greater resistance to infections. These characteristics result in a better quality of life in the postoperative period and, in some series, higher long-term survival rates [1].

Due to the limited number of donors, the difficulty of procurement following the norms of asepsis and preoccupation with the transmission of infectious and contagious diseases, new forms of preservation and storing of good quality grafts were required. The first methods used, were more aggressive to valve tissues included ethylene oxide, gamma irradiation, beta-propiolactone, lyophilization but were soon discontinued as the clinical results demonstrated a reduction in their durability when compared with fresh grafts [2-4]. Analysis of the long-term results using fresh homografts created the concept that the
Resultados: De setembro de 1996 a fevereiro de 2005, 1059 corações provenientes de 19 Estados foram recebidos no BVCHSC. Destes, 977 (92,3\%) eram de doadores de morte encefálica. Foram processados 2105 enxertos, e dentre os aórticos e pulmonares analisados, 783 eram da categoria 2, 697 pertenciam à categoria 1 e 186 foram descartados por alterações morfológicas. No total, 433 enxertos recebidos estavam contaminados, sendo a solução de antibióticos eficiente na esterilização de $\mathbf{3 3 0}$ destes casos. Quinhentos e setenta e um $(27,1 \%)$ enxertos foram rejeitados em alguma fase do processo, sendo a contaminação e as alterações morfológicas as causas mais freqüentes. Foram distribuídos 1338 enxertos para 74 instituições de saúde do país, sendo mais comumente empregados na substituição da valva aórtica (529), na correção de cardiopatias congênitas (478) e durante operações de Ross (272).

Conclusões: As atividades do BVCHSC durante estes oito anos de funcionamento foram satisfatórias, atingindo os objetivos propostos.

Descritores: Bancos de tecidos. Transplante homólogo. Criopreservação. Preservação de tecido. durability was directly related to the degree of cellular viability of the tissue at implantation [5].

In an attempt to prefect the preservation of the tissue and increase the availability of grafts for implantation, the technique of cryopreservation was introduced in the 1970s [6]. Apart from cryogenic preservation, this new methodology includes some new concepts such as harvesting achieved using more rigorous aseptic techniques, a reduced warm ischemic time, sterilization in solutions with lower concentrations of antibiotics and programmed tissue freezing in cryoprotectors. The use of these techniques enabled the optimized preservation of the extracellular matrix, with a high index of cellular viability and they are considered, until today, the most efficient form of processing and storing valvar homografts $[7,8]$.

Considering the high prevalence of valve replacements in Brazil, in a poor population without conditions for adequate anticoagulation therapy, the Hospital de Caridade da Irmandade da Santa Casa de Misericórdia in Curitiba in 1996 established the first human heart valve bank in Brazil with the objective of systematically supplying cryopreserved valvar homografts to any institution or heart surgery service of the country [9]. 
The objective of this work was to retrospectively evaluate the data related to procurement, processing, utilization and distribution of grafts over the first eight years of the human heart valve bank.

\section{METHOD}

All the hearts received in the human heart valve bank, between September 1996 and February 2005 were retrospectively analyzed in a systematic study of the processed organs. Identification, initial selection and approach to family members of potential donors were coordinated by the Centers of Notification, Procurement and Distribution of Organs (CNCDO) according to the national guidelines for the procurement of human organs, together with specific additional criteria laid down by the human heart valve bank. Harvesting of organs was performed by surgeons preferably in a surgical center from multiple organ donors (after brain death), heart attack donors or recipients of heart transplantation.

Delivery of the hearts to the human heart valve bank was made following the norms established by the Health Ministry and their receipt was always made by the team of the human heart valve bank.

Harvesting of organs and tissues from a donor was only authorized after screening tests to diagnose infectious and contagious diseases such as a-HIV 1 and 2, a-HTLV I and II, HBsAg, a-HBc, a-HCV, VDRL and Chagas disease. The sum of the cold and warm ischemic times could not exceed 48 hours. Up to May 2001, the ages to accept organs were from newborn babies to 60 years of age for the dissection of aortic valves or up to 65 years old in the case of pulmonary valves. After this date, the maximum limits were reduced to 55 years for aortic valves and 60 years for pulmonary valves. No donations from individuals with infectious, contagious or systemic diseases which could affect the quality of the valvar tissue, active infections or septicemias, malignant diseases (except for primary tumors of the central nervous system), autoimmune diseases, patients submitted to prolonged corticosteroid therapy or those who suffered deaths of unknown causes, were accepted.

The human heart valve bank, by means of an explicatory protocol, suggested that the procurement teams or the CNCDO involved in the harvest of the heart for valves used a method considered 'ideal' for the preparation and transportation of the organs, which was evaluated before initiation of dissection and processing of the grafts. Only organs transported in a solution with a temperature of less than $10^{\circ} \mathrm{C}$ were accepted.

Normally the aortic and pulmonary valves were dissected. In some cases, the mitral valves, the descending thoracic and abdominal aortas and the pericardia were also used. Processing of the grafts was made in a class 100 laminar flow chamber (Trox of Brazil, model FLV CL I especial), in ideal conditions of antisepsis.

The internal diameters of the annuli of the pulmonary and aortic valves, as well as the internal diameters of the descending thoracic and abdominal aortas were measured in millimeters $(\mathrm{mm})$. The length of the vessels were measured in centimeters $(\mathrm{cm})$ using rulers.

The dissected grafts were submitted to detailed macroscopic inspection looking for anything that may compromise the functioning after implantation and classified as Category 0 (rejected), 1 (minimal morphological alterations) or 2 (perfect).

The heart grafts were decontaminated in a RPMI 1640 medium with low concentrations of antibiotics $(240 \mu \mathrm{g} / \mathrm{mL}$ cefoxitin, $120 \mu \mathrm{g} / \mathrm{mL}$ lincomycin, $50 \mu \mathrm{g} / \mathrm{mL}$ vancomycin and $100 \mu \mathrm{g} / \mathrm{mL}$ polymyxin B) for 24 to 48 hours at $4{ }^{\circ} \mathrm{C}$.

All the processed grafts were individually submitted to sterilization tests attempting to identify microbiological contamination.

Freezing was performed in a solution containing RPMI 1640 medium $10 \%$ dimethyl sulphoxide and $10 \%$ bovine fetal serum in cryopreservation equipment (Planer model KRYO 10-16 Series III and controller model K10-22, Sanbury-onThames, UK) with a tissue cooling speed of $-1{ }^{\circ} \mathrm{C} / \mathrm{min}$ until the grafts were cooled to $-80^{\circ} \mathrm{C}$. On completing freezing, the grafts were transferred to storage freezers (Sanyo model ultra-low temperature freezer $-152^{\circ} \mathrm{C}-\mathrm{MDF}-1155 \mathrm{ATN}$ or Custom Biogenic Systems, model storage unit S-1500 B, Osaka, Japan) at liquid nitrogen temperatures $\left(-150^{\circ} \mathrm{C}\right)$.

The delivery of the grafts to heart surgery departments was achieved using cryoshipper containers (MVE cryogenics equipment, series AYA03D105, Burnsville, USA), according to the norms established by the Health Ministry.

Only personnel trained by the BVCHSC were authorized to thaw and dilute the cryoprotecting solution of the cryopreserved grafts. Thawing was made rapidly using saline solution at temperatures of 42 to $50{ }^{\circ} \mathrm{C}$ followed by gradual dilution of the cryoprotector using RPMI 1640 medium and $10 \%$ bovine fetal serum.

The rate of overall utilization was determined by the ratio of the total number of grafts released for clinical use and the total number of dissected grafts.

\section{RESULTS}

A total of 1059 hearts from 19 Brazilian states and 218 different health institutions were received in the BVCHSC (Figures 1 and 2). The detail analysis of the hearts received by state per year demonstrated significant seasonal changes as is shown in Figure 3. 


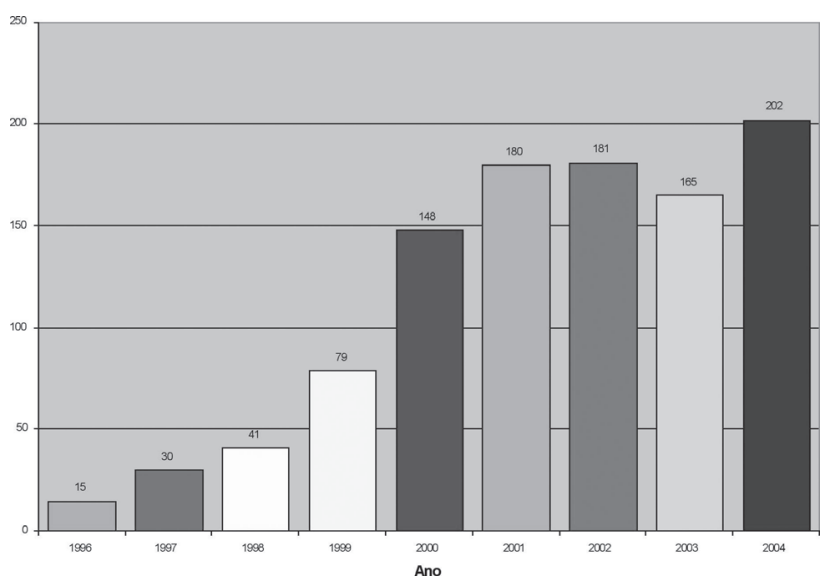

Fig. 1 -Distribution of hearts received by the BVCHSC between September 1996 and December 2004

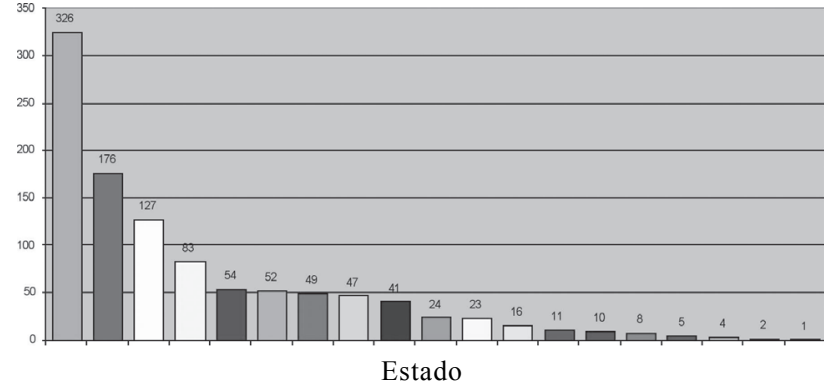

Fig. 2 -Hearts received in the BVCSH stratified by state

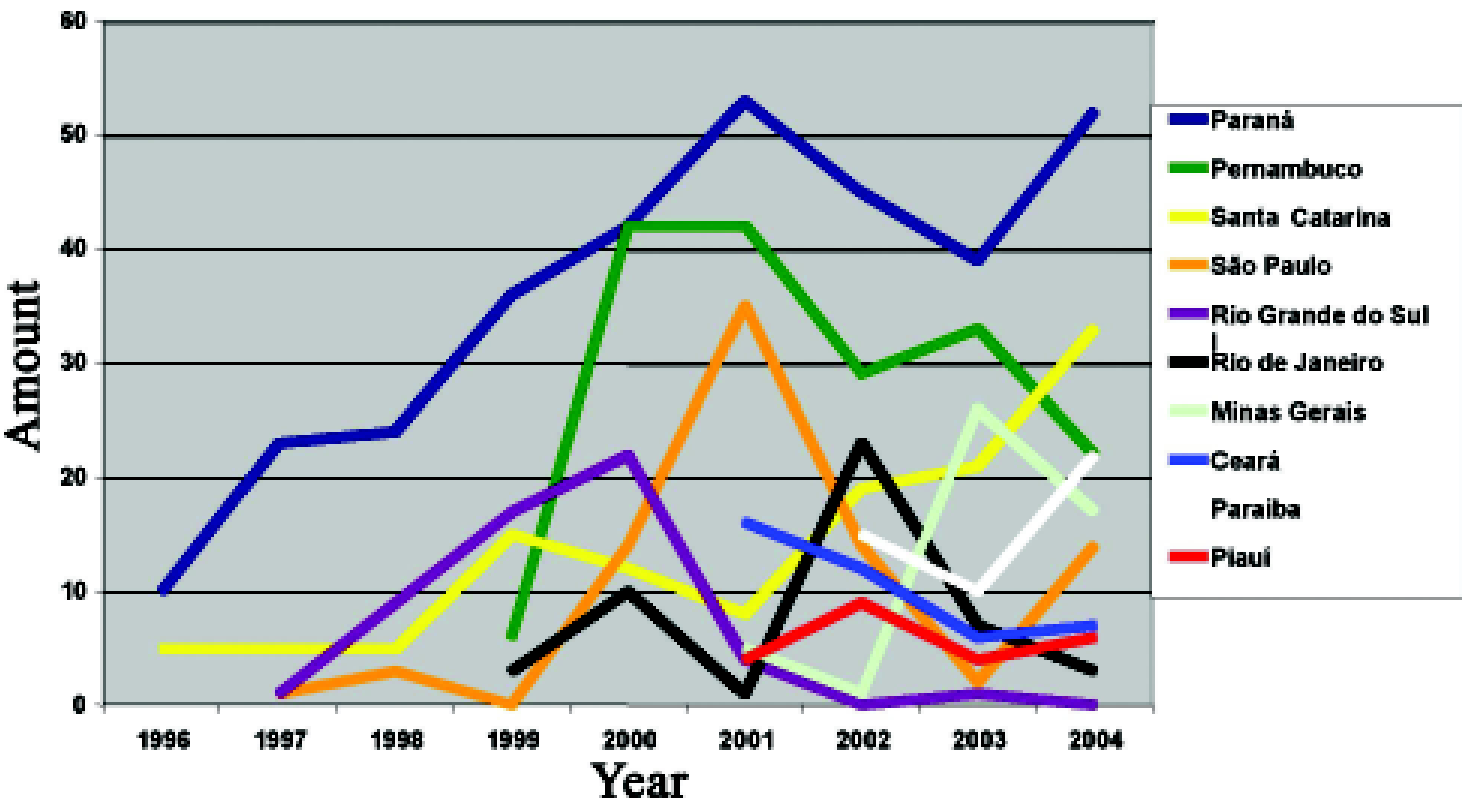

Fig. 3 - Hearts received in the BVCHSC stratified by state / year

Of the organs received, 977 (92.3\%) were from braindead donors, 44 (4.1\%) from heart attack donors and 38 (3.6\%) from heart transplant recipients. The team of BVCHSC was available to receive the organs sent in all cases and in $99.5 \%$ the hearts arrived as had been planned.

Ten $(0.9 \%)$ hearts were not dissected as they were positive for one of the screening serological tests of donors and $142(6.7 \%)$ of the grafts were processed but later rejected for being serologically positive or of low quality. Additionally, $12(0.6 \%)$ of the serologically negative grafts were rejected as the excessive hemodilution of the donors made adequate serological testing impossible.

Two $(0.2 \%)$ hearts were not dissected and two $(0.1 \%)$ valves were processed and later discarded as the maximum 
ischemia time accepted by the BVCHSC was exceeded and in one case there was a loss of grafts as the temperature of the solution used for transportation was inadequate.

The hearts of three donors and 13 aortic valves were not dissected as the ages of the donors were greater than the range accepted by the protocol of the BVCHSC. Additional to these, $6(0.3 \%)$ aortic valves processed were later rejected as the established donor age had been exceeded.

There were three $(0.3 \%)$ cases in which the hearts were not dissected and $18(0.9 \%)$ grafts rejected as the donors presented in clinical conditions that compromised the quality of the valve tissues.

Inadequate preparation of the hearts was responsible for the discarding of three $(0.3 \%)$ organs and five $(0.2 \%)$ grafts.

Of the 922 hearts analyzed, only $177(19.2 \%)$ were packed, prepared and transported to the BVCHSC in an 'ideal' manner. The other $745(80.8 \%)$ were prepared for transportation satisfactorily, however without totally fulfilling the technical recommendations suggested by the BVCHSC. Of the dissected organs that had been correctly packed, 349 grafts resulted. The transportation solution of $43(12.3 \%)$ of these was contaminated and it was possible to decontaminate 39 $(90.7 \%)$. With the other hearts that were inadequately transported, a total of 1491 dissected grafts, the transportation solution of $340(22.8 \%)$ was contaminated and it was possible to decontaminate only $259(76.2 \%)$ after adding an antibiotic solution. Table 1 correlates the source of the contaminated organs with the state of origin.

Two $(0.2 \%)$ hearts were not dissected and 18 heart valves $(0.9 \%)$ were rejected in the process as they presented with lesions caused during the harvesting of the organ which compromised the functioning of the valves.

Of the 1059 hearts received, 2105 grafts were processed of which 1011 (48\%) were aortic valves, $1034(49 \%)$ pulmonary valves, $32(1.5 \%)$ mitral valves, $16(0.8 \%)$ descending thoracic aortas, two $(0.1 \%)$ abdominal aortas and ten $(0.5 \%)$ pericardia. Of this total, $571(27.1 \%)$ grafts were rejected at some stage of the processing.

During the processing, $22(1.0 \%)$ grafts were discarded due to technical errors and there were 12 cases in which the aortic valves were not dissected in addition to those coming from donors older than the maximum acceptable age established by the organ bank. In nine of these cases, the mitral valve was dissected instead of the aortic valve.

The internal diameter of the aortic valve rings released for clinical use varied from 3.5 to $28 \mathrm{~mm}(20.5 \pm 3.4 \mathrm{~mm})$. The most frequently observed diameters ranged from 3.6 to 32 $\mathrm{mm}(23.3 \pm 3.6 \mathrm{~mm})$ with $68.8 \%$ of the valves between 20 and $26 \mathrm{~mm}$.

After macroscopic analysis of the cusps, conduits and myocardial tissue, $138(13.6 \%)$ of the aortic valves and 48
Table 1. Number of hearts with the transportation solution contaminated in respect to state of origin

\begin{tabular}{|c|c|c|}
\hline $\begin{array}{l}\text { Origin } \\
\text { of the heart }\end{array}$ & Hearts harvested & $\begin{array}{c}\text { Hearts } \\
\text { delivered in } \\
\text { contaminated solutions }\end{array}$ \\
\hline Mato Grosso & 4 & $0(0 \%)$ \\
\hline Pará & 8 & $0(0 \%)$ \\
\hline Rio Grande do Norte & 10 & $0(0 \%)$ \\
\hline Sergipe & 1 & $0(0 \%)$ \\
\hline Goiás & 16 & $2(12.5 \%)$ \\
\hline Paraíba & 52 & $8(15.4 \%)$ \\
\hline Piauí & 3 & $6(26.1 \%)$ \\
\hline Santa Catarina & 127 & $44(34.6 \%)$ \\
\hline São Paulo & 83 & $29(34.9 \%)$ \\
\hline Rio Grande do Sul & 54 & $19(35.2 \%)$ \\
\hline Paraná & 326 & $116(35.6 \%)$ \\
\hline Minas Gerais & 49 & $18(36.7 \%)$ \\
\hline Distrito Federal & 5 & $2(40 \%)$ \\
\hline Ceará & 41 & $18(43.9 \%)$ \\
\hline Rio de Janeiro & 47 & $26(55.3 \%)$ \\
\hline Pernambuco & 176 & $117(66.5 \%)$ \\
\hline Alagoas & 11 & $8(72.7 \%)$ \\
\hline Bahia & 24 & $18(75 \%)$ \\
\hline Espírito Santo & 2 & $2(100 \%)$ \\
\hline
\end{tabular}

( ) number between parentheses represents the percentage of hearts with the transportation solution contaminated

(4.6\%) of the pulmonary valves were classified as Category 0 and discarded. Of the 707 aortic grafts released, 288 (40.7) were considered perfect (Category 2), and 419 (59.2\%) presented with minimal morphologic alterations (Category 1 ), which would not affect valvar function. For the 773 released pulmonary grafts, 495 (64\%) were classified as Category 2 and $278(36 \%)$ as Category 1 . The correlation between the donor's age and the incidence of rejection for morphologic alterations of the grafts is demonstrated in Table 2. Note the high degree of rejection of aortic valves from over 45 to 50 -year-old donors. 
Table 2. Rejection of aortic and pulmonary valves due to structural alterations correlated to the age of the donor

\begin{tabular}{|c|c|c|c|c|}
\hline \multirow{3}{*}{$\begin{array}{l}\text { AGE OF } \\
\text { DONORS (YEARS) } \\
\end{array}$} & \multirow{2}{*}{\multicolumn{2}{|c|}{ DISSECTED VALVES }} & \multicolumn{2}{|c|}{ VALVES REJECTED } \\
\hline & & & DUE T & TIONS \\
\hline & Aortic & Pulmonary & Aortic & Pulmonary \\
\hline $0-10$ & 77 & 77 & $3(3.9 \%)$ & $1(1.3 \%)$ \\
\hline $11-20$ & 192 & 194 & $11(5.7 \%)$ & $5(2.5 \%)$ \\
\hline $21-30$ & 215 & 216 & $7(3.2 \%)$ & $11(5.1 \%)$ \\
\hline $31-40$ & 161 & 164 & $12(7.4 \%)$ & $7(4.3 \%)$ \\
\hline $41-50$ & 218 & 219 & $52(23.9 \%)$ & $9(4.1 \%)$ \\
\hline $51-60$ & 118 & 132 & $50(42.4 \%)$ & $15(11.3 \%)$ \\
\hline $61-70$ & 5 & 5 & $3(60 \%)$ & 0 \\
\hline
\end{tabular}

() number in parentheses represents the percentage of valves rejected due to structural alterations

Of the 2105 processed grafts, $1616(76.8 \%)$ were not contaminated in any of the processing stages and 433 (20.6\%) presented bacterial and/or fungal contamination in the transportation solution. The most frequent germs were Staphilococcus sp, Serratia sp and Escherichia coli. Of these $330(76.2 \%)$ were decontaminated after the addition of the nutrient solution containing low concentrations of antibiotics and $103(23.8 \%)$ were discarded for persistent contamination. In $56(5.3 \%)$ cases, the transportation solution was free from contamination however pathogenic germs were detected in some other stage of processing.

A total of 1913 grafts were cryopreserved, of which five $(0.3 \%)$ were rejected as they had freezing curves outside of standards established by the BVCHSC.

In the period studied, 1338 grafts were distributed to and implanted in 74 health institutions of 17 Brazilian States. Of these $663(49.5 \%)$ were aortic valves, $637(47.6 \%)$ pulmonary valves, $21(1.6 \%)$ mitral valves, eight $(0.6 \%)$ pericardia, eight $(0.6 \%)$ descending thoracic aortas and one $(0.07 \%)$ abdominal aorta. Annual stratification of grafts distributed by the BVCHSC is illustrated in Figure 4.

In spite of the progressive growth in utilization of homografts in several Brazilian States, Paraná was responsible for more than half of the implantations (Figure 5).

Of the 1338 grafts utilized, 458 were implanted in Santa Casa of Curitiba and so, eliminating transportation. Of the other $880(65.8 \%)$ cases, the transportation was made utilizing cryoshipper equipment and in no cases was the temperature of the containers compromised. However, delays in the return of cryoshipper were the reason that seven cryopreserved heart valves sent as extra grafts were lost, due to the expiry of the validity date of transportation established by the BVCHSC. On one occasion, a mistake by the BVCHSC team occurred when the cryoshipper was sent without the

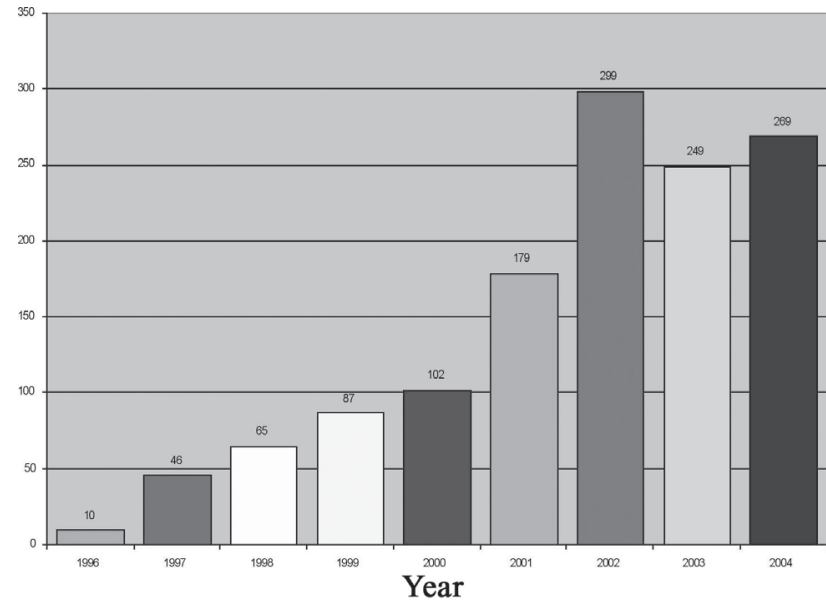

Fig. 4-Distribution annual of the grafts between September 1996 and December 2004

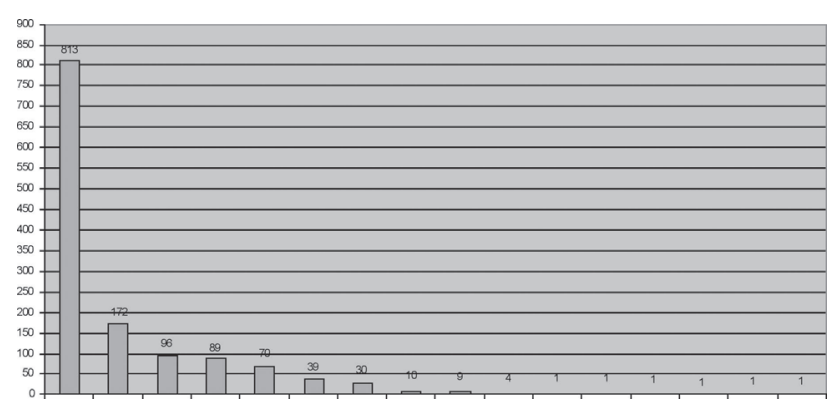

Fig. 5 - Distribution of the grafts by state 
requested valves, which made implantation impossible.

The BVCHSC performed 35 training courses in which 175 professionals were qualified to thaw and dilute the cryoprotectors solution of cryopreserved grafts. Of these $66(37.7 \%)$ had previously made at least one thawing and dilution course. One thawing was made by a person not trained by the BVCHSC.

Of a total of 1331 thawed grafts, $38(2.8 \%)$ were not utilized in operations for the following reasons: $16(42.1 \%)$ due to changes in the surgical procedure, $15(39.5 \%)$ because the conduits were torn, $3(7.9 \%)$ due to deaths before implantation, $2(5.3 \%)$ because of discrepancies between the nominal measurements of grafts and those observed during the surgery, one $(2.6 \%)$ because of problems during thawing and one $(2.6 \%)$ because of an error on the label of the cryopreserved graft.

Among the 1338 grafts transported, 71 (5.3\%) cases of small tears in conduits and another $8(0.6 \%)$ discrepancies between the nominal measurement of grafts and those observed during implantation surgery were reported.

Of the 1338 grafts implanted, 529 were utilized for aortic valve replacement, 478 for congenital heart disease correction, 272 in the reconstruction of right ventricle outflow tracts in the Ross operation, 38 for the correction of descending aorta aneurysms with associated aortic valve disease and 21 for mitral valve replacements. The overall utilization rate in the studied period was $72 \%$ and the time ratio between the number of grafts released for clinical use and implanted in the different services reflects a growing demand for valvar homografts (Figure 6).

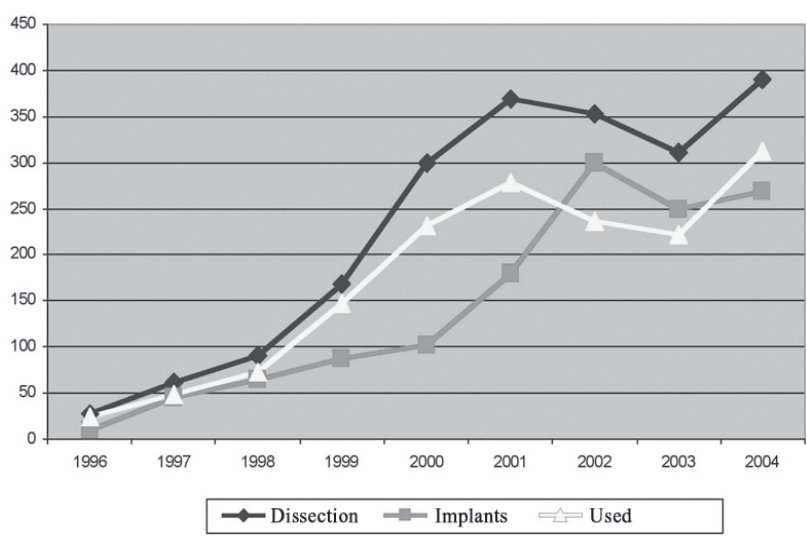

Fig. 6 - Seasonal relationship between the number of grafts processed, released for clinical use and implanted

\section{COMMENTS}

The number of hearts annually received by the BVCHSC revealed gradual and sustainable increase. In 2004, when 202 hearts were received, there was a growth of $673 \%$ in relation to 1997 , when this number was only 30 . Although these data demonstrate a significant improvement in the analysed period, the total number of hearts received is still much below the potential in Brazil. This was well demonstrated when we stratified the hearts received according to the state of origin. There were significant oscillations over time, as well as an imbalance between the possibility of harvest and the number effectively harvested.

In no cases were the hearts not processed due to inappropriate temperatures of the transportation solution and in only $0.28 \%$ of the hearts received, the ischemia time limit recommend by the BVCHSC was exceeded. For certain, the fact that $92.3 \%$ of the hearts were from multiple organ donors, the speed of transportation and availability of BVCHSC technicians to immediately process the hearts were essential to obtain these results. This demonstrates that, in spite of the distances between Brazilian States, regional tissue banks for reasons related to transportation do not seem to be justifiable.

On evaluating the percentage of rejection reported by different homograft banks worldwide, we can see that the results of the BVCHSC (27.1\%) were similar to those reported by others, with morphology and persistent contamination being the principal causes of rejection [1013]. The rate of rejection due to morphologic alterations of aortic and pulmonary valves in the BVCHSC was 9.1\%, with atheromas being the main cause. Analyzing these rates is very subjective though, in consideration of the different selection criteria of donors and valve quality control [14]. Note there is a world tendency to establish more and more rigid protocols for quality control with the goal of having worldwide graft exchange. For this, we believe that in the future the rate of rejection will be even higher [15].

Microbiological contamination of tissue and the effectiveness of the methods employed in sterilization are perhaps the most complex and controversial aspects in the routine of valvar homograft banks. The harvesting procedures are made in environments that range from surgical centers with ideal conditions of antisepsis to contaminated morgues [16]. These variables significantly influence not only the rate of contamination but also the types of germs involved [17]. The success of decontamination, that uses a culture medium with low concentrations of antibiotic, is related to a low level of contamination and sterilized harvesting techniques [18]. 
In our series, $76.8 \%$ of the grafts were not contaminated in any of the processing phases. In $20.6 \%$ of cases it was possible to isolated germs in the transportation solution on receipt. Although a direct comparison with other banks is very difficult, our numbers are similar to be European Homograft Bank (EHB), which reported an index of 25.4\% of contaminated hearts on receipt. In the experience of authors, multiple organ donors resulted in $23.1 \%$ of contaminated hearts; this number increases to $40.6 \%$ when the harvest was made in heart attack donors [10]. Optimization of the organ harvesting process seems to be fundamental to reduce the contamination of the tissues. Of the hearts received by the BVCHSC and which were packed and transported in ideal conditions, the incidence of contamination was $12.3 \%$ and it was possible to sterilize $90.7 \%$. Thus, in 349 grafts received under ideal conditions of transportation, only $1.1 \%$ was discarded due to persistent contamination. For hearts in which the preparation was different to that suggested by the BVCHSC, $22.8 \%$ were contaminated and only $76.2 \%$ could be effectively decontaminated, that is in 1491 grafts received under non-ideal conditions, $5.43 \%$ were rejected for persistent contamination. This stresses that improvement of all phases of donor selection and organ harvest and the adequate training of surgical teams is primordial for tissue banks to establish protocols that result in high quality grafts.

Similar to ischemia times, acceptable age limits of heart valve donors vary. Some tissue banks set maximum age limits of 75 years, whilst others reduce this to 40 years old, as they associate elderly donors with a greater risk of valve degeneration $[16,19,20]$. In our series, we highlight the high rate of rejection of aortic valves from over 40 to 50 year-old donors. For this reason, we reduced the limit of acceptance of aortic valves from 60 to 55 years old.

Transmission of infectious and contagious diseases in transplanted tissues may be minimized by a rigid selection of donors. This includes screening tests for the detection of transmittable diseases, analysis of the donor's records and background and the observations of physical evidence that can suggest or indicate diseases that counter-indicate the use of organs or tissues [21].

Among the tissues processed in the BVCHSC, $97 \%$ were aortic and pulmonary valve homografts, with $69.6 \%$ of the aortic valves with a internal diameter between 18 and $24 \mathrm{~mm}$ and $68.8 \%$ of the pulmonary valves measuring 20 and $26 \mathrm{~mm}$. Considering that aortic valve diseases are frequently associated to the dilation of its ring, there are many requests of aortic valves with diameters greater than those available. Thus it is very important that the surgeons are familiar with techniques to reduce or enlarge the aortic root, to adapt its size and geometry according the sizes of the available homografts. Mistakes in relation to this may lead to stenosis or valve insufficiency [22]. The distribution system of cryopreserved homografts by the BVCHSC was satisfactory. As was observed by Goffin et al. (1996), the close relationship between the surgeon responsible for implantation and the team of the bank, helped the choice of adequate grafts in respect to its transportation, thawing and dilution. To us this seems essential for the efficacious performance of the distribution process.

The increased use of cryopreserved homografts distributed by the BVCHSC and the diversity of the Brazilian States where these transplantations were performed demonstrated the growing interest and the wide access of cardiovascular surgeons to this type of valve replacement [23]. The high rate of implantation performed in State of Paraná when compared to other states may be justified by the pioneerism and growing demand for homologous grafts, considering the optimum results obtained $[24,25]$.

The analysis of the overall utilization curve demonstrated the importance of the available grafts and the enthusiasm of surgeons to use them. Between 1998 and 2002 the growing quantity of available grafts provided a significant increase in the number of implants, however, over the last two years the relationship between supply and demand has been less favorable. Our day-to-day life in the BVCHSC indicates that any difficulty in the immediate availability of a graft implicates a lack of satisfaction and discouragement in its use. For this reason we believe complete integration and continuous work between the bank and the CNCDO are very important in order to effectively alter the harvesting system.

\section{CONCLUSIONS}

The analysis of the results of the first eight years of the BVCHSC allows us to conclude that:

1 - Harvest of hearts to process cardiovascular grafts gradually but significantly increased over the analysed period with Paraná, Pernambuco and Santa Catarina being the states that harvested the most.

2 - The organ transportation system established between the airline companies and Health Ministry as well as the availability of the BVCHSC team to receive, process and distribute the grafts were effective.

3 - The two main causes of graft rejection were persistent microbiologic contamination $(4.89 \%)$ and structural alterations $(13.6 \%$ for aortic valves and $4.6 \%$ for pulmonary valves).

4 - There were few graft losses due to technical errors of the harvesting team showing special training for 
harvesting is not necessary.

5 - The contamination rate of transportation solution reduced when the organ was prepared and transported following the suggestions of the Bank.

6 - The sterilization solution adopted was efficacious in the decontamination of $76.2 \%$ of the hearts with contaminated transportation solution.

7 - The technical training for thawing and dilution of the cryoprotector solution enabled the implantation of grafts without the help of the BVCHSC team.

8 - The states that most transplanted valves processed by the BVCHSC were Paraná, São Paulo and Rio Grande do Sul.

9 - The overall utilization rate of grafts dissected by the BVCHSC was $72 \%$.

10- The activities of the BVCHSC related to harvesting, processing, storing and distribution of cardiovascular homologous grafts over the last eight years was satisfactory, achieving the proposed objectives.

\section{BIBLIOGRAPHIC REFERENCES}

1. O'Brien MF, Harrocks S, Stafford EG, Gardner MA, Pohlner PG, Tesar PJ et al. The homograft aortic valve: a 29-year, $99.3 \%$ follow up of 1,022 valve replacements. J Heart Valve Dis. 2001;10(3): 334-45.

2. Barratt-Boyes BG. A method for preparing and inserting a homograft aortic valve. Br J Surg. 1965;52(11):847-56.

3. Longmore DB, Lockey E, Ross DN, Pickering BN. The preparation of aortic-valve homografts. Lancet. 1966; 2(7461):463-4.

4. Malm JR, Bowman FO Jr, Harris PD, Kowalik AT. An evaluation of aortic valve homografts sterilized by electron beam energy. J Thorac Cardiovasc Surg. 1967;54(4):471-7.
5. Barratt-Boyes BG, Roche AH, Whitlock RM. Six year review of the results of freehand aortic valve replacement using an antibiotic sterilized homograft valve. Circulation. 1977;55(2):353-61.

6. Angell JD, Christopher BS, Hawtrey O, Angell WM. A fresh viable human heart valve bank: sterilization, sterility testing, and cryogenic preservation. Transplant Proc. 1976;8(2 Suppl 1):139-47.

7. Watts LK, Duffy P, Field RB, Stafford EG, O'Brien MF. Establishment of a viable homograft cardiac valve bank: a rapid method of determining homograft viability. Ann Thorac Surg. 1976;2(3):230-6.

8. O'Brien MF, Stafford EG, Gardner MA, Pohlner PG, McGiffin DC. A comparison of aortic valve replacement with viable crypreserved and fresh allograft valves, with a note on chromosomal studies. J Thorac Cardiovasc Surg. 1987;94(6):812-23.

9. Costa FD, Costa MB, Costa IA, Poffo R, Sardeto EA, Matte E. Clinical experience with heart valve homografts in Brazil. Artif Organs. 2001;25(11):895-900.

10. Goffin YA, Van Hoeck B, Jashari R, Soots G, Kalmar P. Banking of cryopreserved heart valves in Europe: assessment of a 10year operation in the European Homograft Bank (EHB). J Heart Valve Dis. 2000;9(2):207-14.

11. Raanani E, Groysman M, Erez E, Berman M, Kogan A, Aravot $D$ et al. Establishment of a heart valve homograft bank using existing facilities. Transplant Proc. 2003;35(2):634-5.

12. Verghese S, Padmaja P, Sindhu B, Elizabeth SJ, Lesley N, Cherian KM. Homograft valve bank: our experience in valve banking. Indian Heart J. 2004;56(4):299-306.

13. Jashari R, Van Hoeck B, Tabaku M, Vanderkelen A. Banking of the human heart valves and the arteries at the European Homograft Bank (EHB): overview of a 14-year activity in this international association in Brussels. Cell Tissue Bank. 2004;5(4):239-51.

14. Mestres C-A, Agusti E, Martinez A, Cabrer C, Manyalich M, Cartaña $\mathrm{R}$ et al. Cardiovascular tissue banking in the noncadaveric setting: ten-year experience of a university hospitalbased bank with active organ donation program. J Heart Valve Dis. 2000;9(4):523-9.

15. Von Versen R, Mönig H-J, Salai M, Bettin D. Quality issues in tissue banking: quality management systems - a review. Cell Tissue Bank. 2000;1(3):181-92.

16. Lange PL, Hopkins RA. Allograft valve banking: techniques and technology. In: Hopkins RA, ed. Cardiac reconstructions with allograft valves. New York:SpringerVerlag;1989. p.37-63. 
17. Gall K, Smith S, Willmette C, Wong M, O’Brien M. Allograft heart valve sterilization: a six-year in-depth analysis of a twenty-five-year experience with low-dose antibiotics. J Thorac Cardiovasc Surg. 1995;110(3):680-7.

18. Strickett MG, Barratt-Boyes BG, MacCulloch D. Disinfection of human heart valve allografts with antibiotics in low concentration. Pathology. 1983;15(4):457-62.

19. O’Brien MF, Stafford EG, Gardner MA, Pohlner PG, McGiffin $\mathrm{D}$, Johnston $\mathrm{N}$ et al. The viable cryopreserved allograft aortic valve. J Card Surg. 1987;2(2):153-67.

20. Parker R. An international survey of allograft banks. In: Yankah AC, Yacoub MH, Hetzer R, eds. Cardiac valve allografts: science and practice. Darmstadt:Springer;1997. p.5-9.

21. Eastlund T. Infectious disease transmission through cell, tissue, and organ transplantation: reducing the risk through donor selection. Cell Transplant. 1995;4(5):455-77.
22. O'Brien MF. Allograft aortic root replacement: standardization and simplification of technique. Ann Thorac Surg. 1995;60(2 Suppl.):S92-4.

23. Goffin Y, Grandmougin D, VanHoeck B. Banking cryopreserved heart valves in Europe: assessment of a 5-year operation in an international tissue bank in Brussels. Eur J Cardiothorac Surg 1996; 10: 505-12.

24. Gerola LR, Araújo W, Kin HC, Silva GE, Pereira Filho A, Vargas GF et al. Cryopreserved aortic homograft for aortic valve replacement: immediate results. Arq Bras Cardiol. 2004;83(4):280-3.

25. Costa F, Haggi H, Pinton R, Lenke W, Adam E, Costa IS. Rest and exercise hemodynamics after the Ross procedure: an echocardiographic study. J Card Surg. 1998;13(3):177-85.

26. Costa FDA, Poffo R, Matte E, Sardeto EA, Schneider RA, Adam EP et al. Cinco anos de experiência com a operação de Ross: o que aprendemos? Rev Bras Cir Cardiovasc. 2000;15(2):109-28. 